\title{
5. 新しい処置用ヒステロファイバースコープ
}

\author{
（川崎市立川崎病院産婦人科）
}

林保 良・斉 藤 寿一郎・友 松 守 彦

関賢一・岩田嘉 行

\section{目的}

今回われわれは富士写真光機の協力を得て新し い屈曲可能な軟性部分と硬性部分をもつ処置用七 ステロファイバースコープを開発し 臨床に応用し たので報告する.

\section{方 法}

器具: 処置用ヒステロファイバースコープ.

外径 $4.8 \mathrm{~mm}$, 視野角 $90^{\circ}$, 観察深度 $1 \sim 50 \mathrm{~mm}$, チャンネル径 $2 \mathrm{~mm}$, 有効長 $205 \mathrm{~mm}$, 全長 $590 \mathrm{~mm}$, 先端の上 $100^{\circ}$, 下 $90^{\circ}$ まで屈曲可能の軟性部, 中 間の硬性部, その近位側の各方向 $45^{\circ}$ まで自由に 固定できるフリーストップ機能をそなえた半硬性 部扎よび本体から構成される。硬性部には軸を左 右計 $140^{\circ}$ まで捻転できるローテーション機能が あり先端の屈曲機能と合わせ子宮内の目標部位ま で直接到達させることが可能である.

その臨床応用は外径 $3.7 \mathrm{~mm}$ の診断用ヒステロ ファイバースコープによる観察終了後ひきつづき 使用するのを原則とし頝管拡張拉よび麻酔はまっ たく不要であった。

\section{対象および成樍}

使用対象例は以下の 4 群に大別される.

1. 直視下生検

1987 年 8 月より 1988 年 7 月までの間に川崎市 立川崎病院を訪れた患者に外径 $3.7 \mathrm{~mm}$ の診断用 ヒステロファイバースコープを用いて診断した内 膜ポリープ 21 例, 粘膜下筋腫 16 例, 内膜増殖症 7 例, 頝管ポリープ 6 例, 子宮体癌 4 例, その他
6 例の計 60 例飞直視下生検を行った。宮体癌 の 4 例は悪性，他は良性と適正に診断し得た。

2 . 経頝管的卵管再疎通術 (TCRC)

卵管間質部閉鎖の不妊患者 7 例（片側閉鎖 3 例, 両側閉鎖 4 例）に全身麻酔下に腹腔鏡の監視下で 処置用スコープを子宮内に挿入する。 あらかじめ 処置用チャンネルに挿入したカテーテルを卵管内 に $1 \mathrm{~cm}$ まで進め, 同時に注射器を用いてカテーテ ルの近位端から加圧し再疎通性をはかる。これで 成功した場合，ひきつづきインジゴカルミンを注 入乙腹腔鏡で卵管采部からの流出を確認する。不 成功の場合は経皮的冠動脈拡張用バルンカテーテ ルまたはそのガイドワイヤーを卵管口内に挿入し 再疎通性をはかった。片側閉鎖の全例に通過性の 回復が見られ，両側閉鎖の 1 例は片側，3例は両 側の通過性回復が見られた。

\section{3. 子宮鏡下絨毛採取術(HCVS)}

超音波断層法の併用で娃娠 $7 \sim 14$ 週の人工中絶 症例に中絶手術に先立ち子宮直視下の䋐毛採取を 行った. 19 例に执いて充分な採取に成功し， 3 例 に拈いて採取に失敗した。

4. 除去困難な IUD の抜去

5 例の患者に実施し，困難なく除去した。

\section{結 論}

今回開発した処置用ヒステロファイバースコー プは多くの子宮内操作を可能としスコープの外径 と操作性に打いて硬性鏡あるいはその Albaran bridge 装置による間接的操作より優れており, 産 婦人科診療に有用な器械と考える。 